DOI: 10.52363/passa-2021.1-4

UDC: 338.242: [338.45:378]

Karpeko Nadiya, Ph.D. in Public Administration

National University of Civil Defense of Ukraine, Kharkiv

ORCID ID: 0000-0002-9091-1646

\title{
ORGANIZATIONAL AND ECONOMIC MECHANISMS OF HIGHER EDUCATION DEVELOPMENT IN MARKET CONDITIONS
}

The article analyzes the problem of forming an organizational and economic mechanism that would ensure stabilization, normalization of the economic situation in higher educational establishments, their innovative development in the conditions of market relations. The experience of countries with developed market economies shall be considered.

Key words: education, higher school, modernization, education expenditure, budgetary financing

Problem statement. The socio-economic significance of higher education, its role in scientific and technological progress, the spiritual life of society, in the development and qualitative improvement of the whole economy are well known. The competition of countries in the economic field is reduced in modern market economy to competition in science and technology and, consequently, to competition in the training of qualified personnel in higher education.

Ukrainian higher education, in contrast to foreign ones, has matured in the depths of the state and political system, which is radically different from the current one. That is why its entry into the new socio-economic conditions has created many problems, the choice of solutions which, of course, is associated, in our opinion, with the study of the 
experience of educational systems in market economies.

Analysis of recent research and publications. A number of studies conducted by both domestic and foreign scientists and specialists in the field of higher education are devoted to the problems of the functioning of higher education in market conditions. This, for example, the work of GS Becker, G. Berhorn, D. Grayson, W.M. Zuev, A.G. Androschuk and some other authors.

The purpose of the article is to analyze the directions of formation of the organizational and economic mechanism of higher education management, and considers the experience of countries with developed market economies.

Statement of basic materials. The development of the theory and practice of university management was significantly influenced by two main trends that determined both the main directions of development of higher education systems in different countries and the content of organizational and structural reforms of higher education carried out in them during the 1960-1970's. These trends were the centralization of management at the upper level and the diversification of types of universities and their curricula, accompanied by the decentralization of management at the regional and municipal levels.

The centralization of administration at the upper, national, level is due to the growing role of higher education in ensuring the competitiveness of countries in the world market and strengthening their position in the global economic community, rising costs of higher education and the need for tighter control over spending efficiency. allocated by the state, for the needs of higher education, as well as increased requirements for the quality of education and research that meet the level of modern production, development of science and culture. The centralization of higher education management has found concrete expression in the development of national policy in this important area, the development of strategies for the development of universities and other higher education institutions, setting priorities in the allocation of financial resources, implementation of state programs to assist students. These issues are addressed by the central government in the field of higher education: in the United States - the Ministry of Education; in Japan - the Ministry of Education, Science and Culture; in the United 
Kingdom, the Ministry of Education and Science; in France, the Ministry of National Education; in Germany - the Federal Ministry of Science and Education. Despite some differences in names, the main functions of these organs are approximately the same.

Decentralization of administration at the regional level shall be caused by the specific features of the geographical location of specific regions, the conditions of their economic development, social and demographic differences, as well as established traditions and practices.

Assessing and understanding the importance of higher education for the economic development of the regions, the governing bodies of the latter integrate higher education development plans into regional economic development plans. The most typical examples in this regard are Japan, the major US states, some German states, the Scandinavian countries.

In parallel with the governing structures, but in close connection with them, in many countries there are coordinating bodies that solve important tasks for the management of higher education institutions. In the United States - coordination councils in a number of states; in Germany - the Standing Conference of Land Ministers; in France, the National Council for Higher Education and Research; in Great Britain - the committee of vice-chancellors and rectors of universities and so on [3].

The most important problems in the field of higher education administration, both in theoretical and practical terms, are to achieve a reasonable balance between public administration and university autonomy, university administration and their funding.

Regarding the issues of state control and autonomy of universities in foreign countries, first of all, it should be noted that in the administrative aspect of state control is one of the methods of management, and autonomy - one of the functions of the management process.

Already at the beginning of the XX century. university autonomy has become a kind of academic tradition and a world trend for all European universities. By gaining autonomy, universities take responsibility for the quality of teaching and research. A clear example in this regard is the universities of the Netherlands, which have declared 
that the quality of education is their own task and responsibility, and that the problem of university autonomy is primarily linked to funding. A number of experts argue that many changes in the relationship between government and the university are due to the concept of "economic rationalism", the belief that market mechanisms are faster than the state, will make universities more economically efficient and better managed.

In the United Kingdom, where universities have more autonomy than in Europe, it is also recognized that the market and competition are the main drivers of improving university education. The policy of the British government in this matter is as follows:

- $\quad$ Universities should be less dependent on public funding and rely more on a variety of sources of income;

- the allocation of the state for the remuneration of teachers and research activities should be separated. The work of teachers should be paid depending on the number of students and the level of education, and research should be funded only in those universities where there is sufficient scientific potential;

- Universities should be funded by the state under contracts for teaching, research and services;

- $\quad$ Universities must find additional sources of income (education of foreign students, the implementation of continuing education programs and the like).

It is expected that as a result of the implementation of these principles, universities will become viable, dynamic, and less dependent on the state.

However, with a fairly high degree of autonomy and addressing a wide range of issues on their own, including the distribution of funds between tuition and research, British universities are at the same time severely limited in their development, for example, in size. As a rule, universities and their leaders understand that their own plans must fit into the framework of national needs and capabilities.

Public universities in France as institutions of a scientific and cultural nature are also legally autonomous. Article 20 of the French Higher Education Act of 1984 states that higher education institutions, as public institutions of a scientific, cultural and professional nature, have the status of a legal entity and have autonomy in the fields of 
education, research, administration and finance. At the same time, the university's relations with the state are regulated by contracts that universities enter into with public administration bodies. They record the obligations of universities to the state in the development of higher education and research and the obligations of the state to universities to provide financial resources and open teaching positions.

It follows that the public education system in France is still strictly centralized. The functioning of the higher education system shall be regulated by national legislation, decrees and instructions of public administration bodies. The structure and functions of higher educational establishments, curricula and programs, despite the university autonomy declared by the relevant laws, are largely determined by the instructions of the Ministry of National Education.

The direct management of higher education in France shall be carried out by:

- Directorate of Higher Education, which solves operational issues of higher educational establishment;

- $\quad$ Directorate of Higher Education Personnel, which solves personnel issues;

- $\quad$ administrative and financial services of higher education and research.

At the same time, an important role in the management of universities by the state shall be given to regional structures. The territory of France is divided into 28 educational districts (academies), each of which includes several (usually 4-5) administrativeterritorial departments. The academy is headed by the rector (chancellor of the academy), but during the state educational reform of 1982 there was some decentralization of education management. Academies and local governments have been given more rights. Laws enacted in 1983 expanded the scope for decentralization and led to a redistribution of responsibilities between local authorities and the state. However, the ministry continues to define higher education policy. Rectorates have created structural units that oversee the financing of capital construction and technical equipment of universities and other institutions of national education [2].

In Italy, university autonomy shall be guaranteed by Article 33 of the country's Constitution. However, this autonomy is limited by the fact that universities, like other 
universities, having the status of a legal entity and being public institutions, are included in the state structure as its constituent elements. Accordingly, all university staff are classified as civil servants. In general, we can say that the legislation that existed until recently, strictly regulated the activities of universities.

In 1991, the newly created Ministry of Science and Universities of Italy developed a bill on the autonomy of the university education system, which recognizes universities as fully autonomous in addressing issues of their organizational structure, curriculum content, forms and methods of management.

Unlike European ones, American universities enjoy more autonomy and have more academic freedoms. In their teaching and research activities, they rely mainly on public rather than government agencies. The latter is due in part to the fact that under the US Constitution, higher education is the responsibility of state governments, not the federal government. One cannot ignore the fact that, unlike in Europe, the private sector of the higher education system plays a more important role in the United States. Thus, in 1997 it accounted for 74 of 156 universities and 1,493 of 1996 four-year colleges. In general, more than $70 \%$ of universities and four-year colleges are in the private sector. At the same time, the number of students in the private sector is much lower than in the public sector.

There are five levels of administrative management in American colleges and universities, each of which is clearly defined and has its own specific functions within the institutional structure.

In the field of administrative management in US universities have much in common. In all cases, the highest level of administration is managerial. For public universities, it is a governing or coordinating council at the state level (or the state's leading university); for private colleges and universities, the Board of Trustees or the Board of Governors at the institutional level.

The main function of such councils is to develop a general financial and academic policy that should ensure the effectiveness of the functioning of universities; exercising general control over lands, buildings and other property belonging to the university; 
control over all its expenses.

It is noteworthy that if the university successfully performs its functions of teaching and finds the necessary financial resources for research, it enjoys complete freedom in conducting these studies, discussing and publishing their results.

According to the Basic Law of Germany and the General Law on Higher Education, the responsibility for the development of education and science in the country rests with the land and federal authorities, but the latter perform only coordinating functions. Land parliaments (landtags) and governments, taking into account local conditions, develop the main directions of policy in the field of higher education, create the necessary conditions for the activities of universities, allocate funds for their financing.

The activity of higher educational institutiestablishments shall be regulated by statutes approved by land and state educational bodies. Universities are given independence in determining its structure, content and methods of teaching, in the organization of research, distribution of finances.

Each university has self-governing bodies: the Academic Council and the Board of Trustees, which decide on budget issues, the creation and abolition of university departments, the implementation of relations with foreign universities [3].

At the head of a Japanese university is the president, who heads the university senate, which is an advisory body. The Senate reviews the university budget, oversees the work of faculties and research institutes, deals with issues of coordination and management, the creation and abolition of faculties and their departments, regulates the number of students and teachers.

Summing up the analysis of the problem of university autonomy, it should be noted that it is far from solved, so it, as in the past, is discussed with great interest in many countries. Now, new factors have appeared that complicate the search for the best solution that satisfies all stakeholders: the state, the academic community, socioeconomic structures, society as a whole. The most important of these factors is the emergence of a trend towards mass higher education. In the XXI century. this trend will 
develop rapidly and will cover more and more countries seeking to reach the world level. Of course, those of them will succeed where a competitive economy will be created, which in turn depends on the competitiveness of the labor force and, consequently, the education system, above all higher education. In these circumstances, the state, interested for political, economic and strategic reasons in strengthening its position in the world economic community and the world market, can not but interfere in the affairs of higher education and exercise some control over its activities, reasonably limiting the autonomy of universities.

Therefore, it is quite possible to agree with the opinion of a number of foreign experts who believe that full or absolute autonomy is not needed. Autonomy does not give universities an unconditional opportunity to expand at will or to develop only those areas that interest them. At the same time, the university must respond to the needs of society and the state, setting current directions of development, the ceiling of its expansion, respecting the reasonable limits of financial resources from all sources of their entry.

Considering the financing of higher education, it should be noted that the second half of the XX century was characterized by the rapid development of these systems in all countries of the world, regardless of their affiliation to geographical regions or groups.

The annual growth rates of student contingents in this period were different. In 1960-1970, they accounted for $9.1 \%$ of the world as a whole; in 1970-1975-6.1\%; in 1975-1980 - 3.7\%; in 1980-1990 - 2.7\%. In the group of developing countries, these indicators were higher than the world average, in the group of developed countries lower. However, the absolute number of students in developed countries did not decrease and in 1995 in the United States was 14,473.1 thousand people; in Japan 2,899.1 thousand; in France - 2,074.6 thousand; in Germany - 1,875.1 thousand; Italy 1,682.0 thousand; Great Britain - 1,528.4 thousand people. [4]. To maintain a high rate of development of education, appropriate financial resources were needed, much of which came from the state budget. During 1960-1970, there was an increase in the share 
of GNP allocated by states for education; in the 1960's, for example, the growth rate of education expenditures was twice the growth rate of GNP.

Then they decreased slightly, but the growth continued until 1980, when there was a tendency to stabilize and even decrease.

The decrease in the share of GNP allocated to education is caused not by a reduction in the need for education, but by a constant increase in state budget tensions in many countries, due, on the one hand, to declining business activity and, consequently, lower tax revenues. - increasing competition between applicants for increased public funding, in which education has been somewhat pushed to the background.

All of the above led Western researchers of funding issues to conclude that the education systems of most countries are in a crisis zone, the depth of which is much greater than macro statistics show, and that it will take a long time to find out if new approaches are not found and alternative sources of funding in this area.

At the same time, it should be noted that the current financial crisis in the education systems of foreign countries, especially industrialized ones, which Western experts say is not catastrophic - there are no problems with the survival of the education sector or its salvation. Rather, it is a question of inconsistency of volumes of financing of sphere of formation of that role which is given to it in maintenance of competitiveness of the states in the XXI century. This will require a significant increase in the educational level of the total workforce, the quality of professional education of specialists in all areas and levels of training.

However, many countries, including the United States and the European Union (EU), are researching and finding new ways to finance education, as well as new forms of relationship between the state and the higher education system. In a number of countries, such as Germany and the United Kingdom, public authorities link the university's demands for greater autonomy with a reduction in their funding from the state budget, saying: "If you want more autonomy, you will learn how to make money."

Finance, according to a study by the Organization for Economic Co-operation 
and Development (OECD), is a means of solving many problems, and the financial mechanism serves not only as a tool for allocating to consumers, but also as a control system and an important two-way communication channel. The conditions under which the allocation is proposed indicate the priorities of the persons allocating them; ways of their use, the corresponding preferences of consumers. Therefore, the study of higher education funding can help to understand not only the real goals and objectives behind political rhetoric, but also the differences between the priorities of those who allocate funds and those who consume them [1].

OECD countries have different approaches to defining higher education funding policies. Some of them consider it necessary to maintain a high level of spending per student, but to limit admission to universities, allowing higher education to only a small number of the most capable high school graduates. In other countries, two or more levels of higher education are established and it is easier for students to enter the cheapest of them. A number of states have imposed restrictions on the most expensive areas of study, such as medicine or engineering, for which the economic needs of graduates are sufficiently clear. At the same time, they do not limit admission to less expensive areas, such as philology and social sciences.

Funding is usually provided at three levels: national, regional and local. The share participation of certain state structures in funding depends on many factors, in particular, the traditions of the country and the policy pursued in the field of higher education.

However, usually, the higher the level of education, the greater the state's participation in its financing. In Germany, the United States, Canada, the main difficulty in financing higher education falls on the budgets of lands, states or provinces, while in other countries it is carried out through the central government [3].

Today in Ukraine, in connection with the strengthening of socio-economic independence of the regions, it is known that the role of regional governing bodies of higher education, its logistics and financial support is increasing.

Of course, among the positive aspects attracts funding for universities from regional budgets, but given that most regions of Ukraine are subsidized, the 
implementation of such a direction in the near future is unrealistic. At the same time, it is impossible to cover the costs of universities for utilities from the budgets of the territories. Only after clarifying and studying the main global strategic trend of the world higher education system can, based on national traditions and economic features, make an attempt to formulate the economic conditions of higher education in Ukraine, which has entered a transition economy.

Conclusions: Based on the generalization of foreign experience in financing the higher education system as a whole, we can conclude that some positive aspects of the organizational and economic mechanism, subject to stabilization of the economic situation in the country and further market relations, can be applied to domestic higher education.

\section{References}

1. Androshhuk A. G. Osvita u krayinakh yevropejs`koyi spil`noty: struktura i` upravlinnya / A. G. Androshhuk // Problemy nauky. - 2000. - No. 8. - S. 54-60 ; No. 9. - S. 54-59.

2. Vishha osvita Ukrayini - yevropejs 'kij vymir: stan, problemi, perspektivi. Materialy do pidsumkovoyi kolegii MON Ukrayiny (21 bereznya 2008 r.) // Osvita Ukrayini (speczvipusk). - 2008. No. 21-22 (905). - s. 1-23.

3. Kadochnikov S. M. Osobennosti vysshego obrazovaniya kak ekonomicheskogo blaga i nekotorye prakticheskie sledstviya etikh osobennostej // Universitetskoe upravlenie: praktika i analiz. 2001. No. 2. S. $48-49$

4. Teoretiko-prikladni aspekty upravlinnya zakladami osvity: nauk-metod. posib. - K. : Aktual. osvita, 2002. $-312 \mathrm{~s}$. 